\title{
PARTIAL REPLACEMENT OF INORGANIC N FERTILIZER BY USING HUMIC ACID, COMPOST ENRICHED WITH ACTINOMYCES AND SPIRULINA PLATENSIS ALGAE IN STRAWBERRY CV. FESTIVAL
}

EI- Shall,Z. S. A.

Vegetable and potatoes Res. Dept. Hort. Res.Inst. Agric. Res. Center, Giza, Egypt.

\section{ABSTRACT}

During 2009/ 2010 and 2010/ 2011 seasons, the possibility of replacing 25 to $75 \%$ of inorganic $\mathrm{N}$ fertilizer in strawberry cv. Festival by using humic acid at $3 \mathrm{~kg} /$ fed. compost enriched with actinomyces at $4 \mathrm{ton} / \mathrm{fed}$. and Spirulina platensis algae at $3 \mathrm{~L} / \mathrm{fed}$. was investigated.

Results reveal that decreasing percentages of inorganic N from 100 to $50 \%$ out of the suitable $\mathrm{N}$ rate accompanied with the application of humic acid, compost enriched with actinomyces or Spirulina platensis algae resulted in major promotion on growth, diameter and weight of fruit, yield as well as chemical characteristics of the fruits. Application of inorganic $\mathrm{N}$ combined with compost enriched with actinomyces was preferable than using mineral $\mathrm{N}$ plus humic acid in promoting yield quantitively and qualitatively. A supreme and outstanding effect on the production of Festival strawberry was observed when Spirulina platensis algae was added to the present two organic manures rather than using organic manures alone. Unvafourable effects on production were noticed when percentages of mineral $\mathrm{N}$ were reduced to $25 \%$ even with the application of organic and biofertilizers.

The best results with regard to growth, yield and quality of strawberry cv. Festival were obtained by supplying the plants with $50 \%$ inorganic, N. compost enriched with actinomyces at $4 \mathrm{~kg} / \mathrm{fed}$. and Spirulina platensis algae at $3 \mathrm{~L} / \mathrm{fed}$.

\section{INTRODUCTION}

Strawberry is considered as one of the most important vegetable crops grown in Egypt for fresh local consumption and for export especially during the period from Dec. to April.

Organic farming is an agricultural practice that raise plants specially vegetable crops without using of synthetic pesticides, herbicides, mineral fertilizers or even plant growth regulators.

Pollution is becoming a serious problem in agricultural regions. For example, various mineral fertilizers and agrochemicals lead to pollution and serious health problems in humans, hence alternative production techniques which employ biological or organic compounds for disease and pest control are needed (Turemis, 2002).

Nitrogen fertilization is an important and limiting factor for growth, nutritional status and fruiting of different strawberry cvs.

Biofertilization using Spirulina platensis algae has become a positive alternative to chemical $\mathrm{N}$ fertilizers (Kannaiyan, 2002). Spirulina platensis algae is a photosynthetic blue green micro algae. It is very beneficial for enhancing growth especially when applied with organic manures (Sanchez, et al., 2003 and Aly et al., 2008). 


\section{EI- Shall,Z. S. A.}

Humic acid $(\mathrm{HA})$ is a heterogeneous mixture of many compounds with generally similar chemical properties; it performs various functions in the soil and on plant growth. One of the functions of HA is the positive effect on the promotion of root development (Rengrudkij and Partida, 2003). Humic substances (HS) are recognized as a key component of soil fertility properties, since they control chemical and biological properties of the rhizosphere (Nardi et al., 2005; Trevisan et al., 2009). The mechanism of humic acid activity in promoting plant growth is not completely known, but several explanations have been proposed by some researchers such as increasing cell membrane permeability, oxygen uptake, respiration and photosynthesis, phosphate uptake, and root cell elongation (Cacco and Dell Agnolla, 1984 and Turkmen et al., 2004). Addition of HA to soil increases the rate of absorption of ions on root surfaces and their penetration into the cells of the plant tissue. Plants show more active metabolism and increased respiratory activity, which are attributed to the intervention of the quinine groups of HA (Petronio et al., 1982). The effect of HA on the availability of $P$ and micronutrients has been given particular attention because of the observed increases in the uptake rates of these nutrients following the application of HA (Ayuso et al., 1996).

Different organic manures had an announced promotion on soil fertility and the release of different nutrients to the plants (Nijjar, 1985).

Previous studies emphasized the great benefits of supplying organic and biofertiliozers along with mineral $\mathrm{N}$ fertilizer on growth and fruiting of vegetables (Fagbenro and Agboola, 1993; Gliessman et al., 1996; Steinegger and Janssen, 1996; Abebe, 2001; Neri et al., 2002; Pringle et al., 2002; Schopplein et al., 2002; Svensson , 2002; Palomaki et al., 2002, Pilanal and Kaplan, 2003; Abu- Zahra et al., 2005; Preusch et al., 2004 and Ameri and Tehranifar, 2012).

The merit of this study was evaluating the effect of replacing mineral $\mathrm{N}$ fertilizer by humic acid, compost enriched with actinomyces and Spirulina platensis algae on growth, yield and fruit quality of cv. Festival strawberry.

\section{MATERIALS AND METHODS}

This investigation was carried out in a private farm situated at talkha, Mansoura district, El- Dakhalia Governorate during winter seasons of 2009/ 2010 and 2010/2011. The soil of the experimental farm was clay in texture. The obtained data of the soil analysis (Wilde et al., 1985) are shown in Table (1). 
Table (1): Analysis of the tested soil:

\begin{tabular}{|l|c|}
\hline Constituents & Values \\
\hline Sand \% & 2.0 \\
\hline Silt \% & 18.0 \\
\hline Clay \% & 70.0 \\
\hline Texture & Clay \\
\hline pH (1:2.5 extract) & 7.91 \\
\hline CaCO \% $_{\text {. }}$. & 1.19 \\
\hline E.C (1: 2.5 extract) & 0.75 \\
\hline O. M. \% & 1.8 \\
\hline Total N \% & 0.09 \\
\hline Available P (ppm) & 2.25 \\
\hline Available K (ppm) & 410 \\
\hline
\end{tabular}
seasons.

The planting dates were the middle of October during 2009 and 2010

This experiment included the following thirteen treatments:-

1-Fertilization with inorganic $\mathrm{N}$ at $60 \mathrm{~kg} / \mathrm{fed}$.

2-Application of $75 \%$ inorganic $\mathrm{N}+$ compost enriched with actinomyces at 4 $\mathrm{kg} / \mathrm{fed}$.

3-Application of $75 \%$ inorganic $\mathrm{N}+$ compost enriched with actinomyces at 4 $\mathrm{kg} / \mathrm{fed}+$ Spirulina platensis algae.

4-Application of $75 \%$ inorganic $\mathrm{N}+$ humic acid at $3 \mathrm{~kg} / \mathrm{fed}$.

5-Application of $75 \%$ inorganic $\mathrm{N}+$ humic acid at $3 \mathrm{~kg} / \mathrm{fed}$. + Spirulina platensis algae.

6-Application of $50 \%$ inorganic $\mathrm{N}+$ compost enriched with actinomyces at 4 $\mathrm{kg} / \mathrm{fed}$.

7-Application of $50 \%$ inorganic $\mathrm{N}+$ compost enriched with actinomyces at 4 $\mathrm{kg} / \mathrm{fed}+$ Spirulina platensis algae.

8-Application of $50 \%$ inorganic $\mathrm{N}+$ humic acid at $3 \mathrm{~kg} / \mathrm{fed}$.

9-Application of $75 \%$ inorganic $\mathrm{N}+$ humic acid at $3 \mathrm{~kg} / \mathrm{fed}$. + Spirulina platensis algae.

10- Application of $25 \%$ inorganic $\mathrm{N}+$ compost enriched with actinomyces at $4 \mathrm{~kg} / \mathrm{fed}$.

11- Application of $25 \%$ inorganic $\mathrm{N}+$ compost enriched with actinomyces at $4 \mathrm{~kg} / \mathrm{fed}+$ Spirulina platensis algae.

12- Application of $25 \%$ inorganic $\mathrm{N}+$ humic acid at $3 \mathrm{~kg} / \mathrm{fed}$.

13- Application of $25 \%$ inorganic $\mathrm{N}+$ humic acid at $3 \mathrm{~kg} / \mathrm{fed}$. + Spirulina platensis algae.

Each treatment was applied three times, one experimental plot per each. Each plot consisted 3 ridges, $5 \mathrm{~m}$. long and $0.7 \mathrm{~m}$. apart occurring an area of $10.5 \mathrm{~m}^{2}$. The distance between plants was $25 \mathrm{~cm}$. Compost enriched with actinomyces at 4 ton/ fed. was added once before planting.

Preparation of compost enriched with actinomyces:

Different layers of plant wastes namely leaves of mangoes and bananas $(250 \mathrm{~kg})$, animal wastes namely F.Y.M. (1000 kg), poultry manure $(250 \mathrm{~kg})$, clover $(50 \mathrm{~kg})$, clay $(50 \mathrm{~kg})$, actinomyces $(100 \mathrm{ml})$ and mature compost $(50 \mathrm{~kg}$ ) were put above ground in area $3 \mathrm{~m}$ length, $2 \mathrm{~m}$ width and 2 $\mathrm{m}$ height. Agitating of those materials was done weekly with adjusting 
moisture till maturity of compost was established. Analysis of compost was done (according to Wilde et al., 1985) and the obtained data are shown in Table (2).

Table (2): Analysis of compost enriched with actinomyces:

\begin{tabular}{|l|c|}
\hline \multicolumn{1}{|c|}{ Characters } & Values on dry weight basis \\
\hline Weight of $\mathbf{~ M}^{\mathbf{3}} \mathbf{( \mathbf { k g } )}$ & 882 \\
\hline Moisture \% & 13.2 \\
\hline pH $(\mathbf{1}: \mathbf{1 0})$ & 7.41 \\
\hline EC $(\mathbf{1}: \mathbf{1 0})(\mathbf{d S} / \mathbf{m})$ & 3.49 \\
\hline Ammonium N (ppm) & 593 \\
\hline Total N \% & 2.0 \\
\hline O. M. \% & 27.2 \\
\hline Organic carbon \% & 15.78 \\
\hline Ash \% & 72.80 \\
\hline C/ N & 1.16 \\
\hline Total P \% & 0.37 \\
\hline Total K \% & 0.33 \\
\hline
\end{tabular}

Inorganic $\mathrm{N}$ fertilizer namely ammonium nitrite $(33.5 \% \mathrm{~N})$ was applied in three equal parts before planting, 30 and 45 days after planting. Humic acid in the source of potassium humate ( $86 \%$ humic acid) at $3 \mathrm{~kg} /$ fed. was applied in three equal batches, 30, 45 and 60 days after planting. Spirulina platensis algae at $3 \mathrm{~L} / \mathrm{fed}$. was added twice at 30 and 45 days after planting.

Spirulina platensis algae was obtained from Microbiology Res. Department, Soil, Soils, Water and Environment Research Center (ARC), Giza, Egypt. The algae was grown in one liter Erlenmeyer flasks containing $500 \mathrm{ml}$ of standard synthetic medium (Zarrouk, 1966) under continuous illumination (2000 lux). The flasks were incubated at $35^{\circ} \mathrm{C} \pm 2{ }^{\circ} \mathrm{C}$. After 30 days of incubation the culture was transferred to glass reactor (4 liter) and maintained under aerobic conditions using filtered compressed air and incubation at $37{ }^{\circ} \mathrm{C}$ for 21 days. Spirulina platensis algae culture concentration of $2.54 \mathrm{~nm}$ was measured spectrophotometeracally at $560 \mathrm{~nm}$ by Leduy and Thorien (1977). Values of $\mathrm{pH}(1.51)$ and dry weight $(2.63 \mathrm{gl}-\mathrm{I})$ were estimated according to Vonshak (1986). Chlorophyll - a $(23.5 \mathrm{mg} / \mathrm{L})$ was determined by the method of Vonshak and Richmond (1988). Some characteristics of Spirulina platensis are shown in Table (2):

Table (3): Some characteristics of Spirulina platensis:

\begin{tabular}{|c|c|}
\hline Characteristics & Values \\
\hline Color & Blue green \\
\hline pH & 10.51 \\
\hline $\mathrm{EC}\left(\mathrm{dScm}^{-1}\right)$ & 19.3 \\
\hline Organic matter (g/ L) & 2.72 \\
\hline Organic carbon (g/ L) & 1.60 \\
\hline Total nitrogen $(\mathrm{g} / \mathrm{L})$ & 0.70 \\
\hline Total phosphorous (g/ L) & 0.50 \\
\hline Total potassium (g/ L) & 2.34 \\
\hline
\end{tabular}


The strawberries plants were subjected to the normal horticultural practices that already applied in the farm except those dealing with inorganic, organic and biofertilization. Complete randomized block design was followed.

\section{Data recorded:}

In each season of the study, plant height $(\mathrm{cm}$.$) and number of leaves$ per plant were recorded at 60 days after planting. Physical and quality characters of the fruits namely fruit weight $(\mathrm{g}$.) and diameter $(\mathrm{cm}$.) were recorded. Early yield (ton/ fed.) (the first three harvest times) and total yield (ton/ fed.) were measured.

Also, chemical characteristics of the fruits namely total soluble solids $\%$ (by handy refractometer) and total acidity (as g citric acid/ $100 \mathrm{ml}$.) (by titration against $0.1 \mathrm{~N} \mathrm{NaOH}$ according to A.O.A.C., 1995) were determined. Sugars namely total and reducing sugars content were measured according to Lane and Eynon Volumetric method (A.O.A.C., 1995) and sucrose \% (by subtracting reducing sugars from total sugars) was calculated. Total anthocyanins were extracted by adding a solvent containing ethanolic, $1.5 \mathrm{~N}$ $\mathrm{HCl}$ and $95 \%$ ethanol $(85: 15 \mathrm{~V} / \mathrm{V})$. The solvent was added at level $(2: 1)$ solvent to sample then the mixture was stored overnight at $4{ }^{\circ} \mathrm{C}$ then filtered on filter paper Whitman No. 1 and centrifuged at $1000 \mathrm{ppm}$ for 15 minutes (Ranganna, 1979). The supernatant intensity was measured by spectrophotometer (model spectro UV - Vis 0216, U.S.A.). L- ascorbic acid content was measured by titration against 2, 6 dichlorophenol endophenol (A.O.A.C., 1995 and Schopplein et al., 2002) and expressed as mg per $100 \mathrm{~g}$ fruit. Total phenol content as percentage was determined by the spectrophotometeric method at $760 \mathrm{~nm}$, using Folin- Ciocalteu reagent and gallic acid as a standard. The fruits were collected from each harvest and deep- frozen. After the harvest, all the samples were aggregated. Chemical analysis of $\mathrm{N}, \mathrm{P}, \mathrm{K}, \mathrm{Ca}$ and $\mathrm{Mg}$ in the fruits were performed (Wilde et al., 1985) (g/ kg DM).

The obtained data were tabulated and subjected to the proper statistical analysis using new L.S.D test at $5 \%$ for comparing different treatment means (Steel and Torrie, 1980).

\section{RESULTS AND DISCUSSION}

\section{1-Growth characters:}

It is clear from data in Table (4) that varying $\mathrm{N}$ management had significant effect on height and number of leaves per strawberry plant by applying 50 to $75 \%$ inorganic $\mathrm{N}$ plus humic acid at $3 \mathrm{~kg} . /$ fed, compost enriched with actinomyces at 4 tons/ fed and Spirulina platensis algae as compared with using inorganic $\mathrm{N}$ completely or using mineral $\mathrm{N}$ at percentages lower than $50 \%$. Application of compost enriched with actinomyces with or without Spirulina platensis algae was significantly more effective in stimulating such two growth characters rather than application of humic acid alone or with algae biofertilizer. In most cases the addition of Spirulina platensis algae to any organic amendments significantly was accompanied with maximizing the promoting effect of organic fertilizers on growth characters as compared with using organic manures alone. A great 


\section{EI- Shall,Z. S. A.}

and significant decline on such two growth characters was observed by using inorganic $\mathrm{N}$ at $25 \%$ even by the application of organic and biofertilizers. The maximum values were recorded on the strawberry plants that received $\mathrm{N}$ via $50 \%$ inorganic + compost enriched with actinomyces at 4 ton/ fed + Spirulina platensis algae at $3 \mathrm{~L} / \mathrm{fed}$. On the other hand, fertilizing the plants with $\mathrm{N}$ through $25 \%$ inorganic + humic acid at $3 \mathrm{~kg} /$ fed alone gave the lowest values. It is worth to mention that using inorganic $\mathrm{N}$ at $25 \%$ significantly reduced the two growth characters as compared by using completely inorganic $\mathrm{N}$. These results were true during both seasons.

The beneficial effect of organic amendments and biofertilization on enhancing soil fertility, uptake and availability of different nutrients, fixing of $\mathrm{N}$ as well as secreting natural hormones namely IAA and $\mathrm{GA}_{3}$, $B$ vitamins, antioxidants and antibiotics could explain the present results (Nijjar, 1985 and Kannaiyan, 2002).

These results are in harmony with those obtained by Fagbenra and Agboola (1993); Gliessman et al., (1996); Preusch et al., (2004) and Ameri and Tehranifar (2012).

\section{2-Diameter and weight of fruit:-}

Data in Table (4) also clearly show that using inorganic $\mathrm{N}$ fertilizer at 50 to $75 \%$ of the suitable $\mathrm{N}$ aside from the two organic materials namely humic acid and compost enriched with actinomyces as well as Spirulina platensis algae significantly was followed by improving diameter and weight of fruit rather than application of mineral $\mathrm{N}$ alone or using $\mathrm{N}$ at $25 \%$ of the suitable $\mathrm{N}$ even with the present organic and biofertilization treatments. The promotion on diameter and weight of strawberries was associated with reducing inorganic $\mathrm{N}$ percentages from 100 to $50 \%$ of the suitable $\mathrm{N}$ along with the application of the two organic manures and Spirulina platensis algae. A significant reduction on fruit weight and diameter was observed with reducing the percentages of inorganic $\mathrm{N}$ from 50 to $25 \%$ out of the suitable $\mathrm{N}$ even with the application of the two organic fertilizers and the biofertilizer algae. Supplying the plants with $\mathrm{N}$ through $50 \%$ inorganic $\mathrm{N}$ plus compost enriched with actinomyces + Spirulina platensis algae gave the maximum values. The minimum values were produced by using inorganic $\mathrm{N}$ at $25 \%$ of the suitable $\mathrm{N}$ with humic acid. These results were true during both seasons.

The beneficial effect of organic and biofertilizers on fruit development was mainly attributed to their positive action on growth nutritional status of the plants as well as the secretion of natural hormones and antioxidants (Kannaiyan, 2002).

These results are in harmony with those obtained by Fagbenra and Agboola (1993); Gliessman et al., (1996); Preusch et al., (2004) and Ameri and Tehranifar (2012).

\section{3-Yield ton/fed.:}

It is also obvious from data in Table (4) that supplying strawberry cv. Festival with the suitable $\mathrm{N}$ through 50 to $75 \%$ inorganic $\mathrm{N}$ plus the two organic fertilizers (humic acid and compost enriched with actinomyces) and the biofertilizers Spirulina platensis algae significantly was favourable for improving the early yield and total yield of Festivals strawberry plants expressed as ton/fed. rather than application of $\mathrm{N}$ completely via inorganic $\mathrm{N}$ 
or when inorganic $\mathrm{N}$ was applied at $25 \%$ out of the suitable $\mathrm{N}$. The promotion was significantly associated with reducing inorganic $\mathrm{N}$ from 100 to $50 \%$ plus the application of humic or compost enriched with actinomyces as well as using Spirulina platensis algae. A significant reduction on the early and total yields was obtained with using inorganic $\mathrm{N}$ at $25 \%$ either with or without organic and biofertilization. Application of $\mathrm{N}$ completely via inorganic form significantly promoted both yields when compared with using inorganic $\mathrm{N}$ at $25 \%$ even with the application of organic and biofertilizers. Supplying strawberry plants (Festival cv.) with $\mathrm{N}$ through $50 \%$ inorganic + compost enriched with actinomyces + Spirulina platensis algae gave the best results with regard to yield. Under such promised treatment, yield reached 13.20 and 12.81 ton/fed. during both seasons, respectively comparing with 7.49 and $7.26 \mathrm{~kg} / \mathrm{m}^{2}$ produced by plant supplied with $\mathrm{N}$ through $25 \%$ inorganic + humic acid alone (without Spirulina platensis algae). Similar trend was noticed during both seasons.

The previous beneficial effects of organic and biofertilizers on growth, fruit development surely reflected on improving the yield.

These results are in harmony with those obtained by Fagbenra and Agboola (1993); Gliessman et al., (1996); Preusch et al., (2004) and Ameri and Tehranifar (2012).

\section{4-Some chemical characteristics of the fruits:}

Data in Tables (5\& 6) clearly show that varying $N$ management for strawberry cv. Festival had significant effect on chemical characteristics of the fruits. Results further reveal that amending the plants with their requirements from $\mathrm{N}$ through 50 to $75 \%$ inorganic $\mathrm{N}$ along with humic acid or compost enriched with actinomyces with or without Spirulina platensis algae significantly was accompanied with improving quality of strawberries in terms of increasing T.S.S \%, total, reducing and non- reducing sugars, total anthocyanins, vitamin $\mathrm{C}$ and fruit content of $\mathrm{P}, \mathrm{K}, \mathrm{Ca}$ and $\mathrm{Mg}$ and decreasing total acidity \% and total polyphenols \% comparing with using $\mathrm{N}$ via $100 \%$ inorganic $\mathrm{N}$ or when the percentage of mineral $\mathrm{N}$ was reduced to $25 \%$ out of the suitable $\mathrm{N}$ even with the application of organic and biofertilizers. A significant unfavourable effects on chemical characteristics of the fruits were observed with reducing inorganic $\mathrm{N}$ from 50 to $25 \%$ out of the suitable $\mathrm{N}$. These was a gradual promotion on fruit quality with reducing inorganic $\mathrm{N}$ from 100 to $50 \%$ as well as the application of any organic amendments either alone or in combination with Spirulina platensis algae. An obvious promotion on chemical quality parameters was noticed with using Spirulina platensis algae with any organic fertilizer in relative to using any organic fertilizer alone. The best results with regard to chemical quality characteristics were obtained with supplying the plants with $\mathrm{N}$ via $50 \%$ inorganic $\mathrm{N}+$ compost enriched with actinomyces + Spirulina platensis algae. Similar trend was observed during the two experimental seasons.

The benefits of organic and biofertilizers on chemical quality of the fruits were mainly attributed to their positive effect on enhancing the biosynthesis of sugars and plant pigments (Nijjar, 1985 and Kannaiyan, 2002). 
EI- Shall,Z. S. A.

4 
J. Plant Production, Mansoura Univ., Vol. 3 (5), May, 2012

5 
EI- Shall,Z. S. A.

6

934 
These results are in approval with those obtained by Pringle et al., (2002); Abu- Zahra et al., (2003); Preusch et al., (2004) and Ameri and Tehranifar (2012). As a conclusion, for promoting growth as well as yield quantitively and qualitatively of strawberry cv. Festival grown under Dakahlia region, it is concluded for supplying the plants with $\mathrm{N}$ through $50 \%$ inorganic (30 kg N/ fed.) plus compost enriched with actinomyces at 4 ton/ fed. + Spirulina platensis algae at $3 \mathrm{~L} / \mathrm{fed}$.

\section{REFERENCES}

Abebe, G. (2001): Effect of manure on some physico-chemical properties of calcareous soil, yield and quality of cowpea (Vigna unguiculata L. Walp.) Under greenhouse. M. Sc. Thesis, University of Jordan, Amman, Jordon.

Abu- Zahra, T. R.; Shatat, F. and Al- Ismail, K. (2005): Production, storage and quality of strawberry (Fragaria x Annassa Duch) grown under organic and conventional systems in a plastichouse in the Jordon Valley. Ph. D. Thesis, University of Jordon, Amman, Jordon.

Aly, M. H. A.; Abdelall- Azza, A. and Moustafa- Soha, M. (2008): Enhancement of sugar beet seed germination, plant growth, performance and biochemical compounds as contributed by extra cellular products. J. Agric. Sci. Mansoura Univ. 33 (12): 8429 - 8448.

Ameri, A. and Tehranifar, A. (2012): Effect of humic acid on nutrient uptake and physiological characteristics of Fragaria ananassa var. Camarosa. J. Biol. Environ. Sci. 6 (16): 77 - 79.

Association of Official Agricultural Chemists (1995): Official Methods of Analysis (A.O.A.C) 14 $14^{\text {th }}$ Ed, Benjamin Franklin Station, Washington, D.C, U.S.A. pp $490-550$.

Ayuso, M.; Hermandez, T.; Garcia, C. and Pascual, J. A. (1996): Stimulation of barley growth and nutrient absorption by humic substances originating from various organic materials. Bioresourc. Technol. 57: 251 $-257$.

Cacco, G. and Dell' Agnolla, G. (1984): Plant growth regulator activity of soluble humic substances. Can. J. of Soil Sci. 64: $25-28$.

Fagbenro, J. A. and Agboola, A. A. (1993): Effect of different levels of humic acid on the growth and nutrient uptake of teak seedlings. J. of Plant Nutr. 16 (8): $1465-1483$.

Giliessman, S, R.; Werner, M. R.; Allison, J. and Cochran, J. (1996): A comparison of strawberry plant development and yield under organic and conventional management on the central California coast. Biological Agriculture and horticulture, 12 (4): $327-338$.

Kannaiyan, S. (2002): Biotechnology of Biofertilizers. Alpha Sci. Inter. Ltd., P.O. Box 4067 Pang Bourne R.68, U.K. Pp. $1-64$.

Leduy, A. and Thorein, N. (1979): An improved method for optical density measurement of semimicro blue green algae Spirulina maxima. Biotechnol. Boeing. 


\section{El- Shall,Z. S. A.}

Nardi, S.; Tosoni, M.; Pizzeghello, D; Provenzano, M. R.; Cilenti, A.; Sturaro, A. Rella, R. and Vianello, A. (2005): Chemical characteristics and biological activity substances extracted from soils by root exudates. Soil Sci. Soc. Of Am. J. 69, 2012 - 2019.

Neri, D; Lodolini, E. M.; savini, G.; Sabbatini, P.; Bonanomi, G. and Zucconi, F. (2002): Foliar application of humic acids on strawberry (cv. Onda). Acta. Hort. $594-302$.

Nijjar, G. S. (1985): Nutrition of Fruit Trees. Published by Mrs Usha Raj Kumar for kalyani, New Delhi pp. 283-302.

Palomaki, V.; Mansikka- Aho, A. M. and Etelamaki, M. (2002): Organic fertilization and technique of strawberry grown in greenhouse. Acta. Hort., 567, 597 - 599.

Petronio, P.; Vitorovic, D. and Jablanovic, M. (1982): Investigations of the biological effects of HA. Acta. Biol. Med. Exp. 7 (1): $21-25$.

Pilanal, N. and Kaplan, M. (2003): Investigations of effects on nutrients uptake of humic acid applications of different forms to strawberry plant. J. of plant Nutri. 26 (4): $835-843$.

Preusch, P. L.; Takeda, F. and Tworkoski, T. J. (2004): N and P uptake by strawberry plants grown with composted poultry litter. Scientia Horticulturae, 102: $91-103$.

Pringle, G. J.; Bussell, W. T. and Perry, F. (2002): Strawberry growth and yield in response to the environment: inducing new production systems. Acta. Hort., 567: 423 - 426.

Ranganna, S. (1979): Manual of Analysis of Fruit and Vegetable Products. New Delhi, India, Tata Mc. Graw- Hill. Publishing company, limited chapter 4: $77-83$.

Rengrudkij, Ph. and Partida, G. J. (2003): The effects of humic acid and phosphoric acid on grafter Hass avocado on Mexican seedling rootstocks. Actas V. Congreso mundial del Aguacate pp. $395-400$.

Sanchez, M.; Bernal- Castilio, C. R. and Rodrigues, I. (2003): Spirulina (Arthrospira), an edible microorganism. A review Universities Scientiorum, 8: 1 Bogota, Colombia.

Schopplein, E.; Kruger, E.; Rechner, A. and Hoberg, E. (2002): Analytical and sensory qualities of strawberry cultivars. Acta. Hort., 567: $805-808$.

Steel, R. G. D. and Torrie, J. H. (1980): Principles and Procedures of Statistics, McGraw- Hill, New York.

Steinegger, D. H. and Janssen, D. E. (1996): Strawberries, plants, selecting and preparing a site, planting and care of strawberries. Institute of Agriculture and Natural Resources, University of Nebraska- Lincoln, $889-897$.

Svensson, B. (2002): Organic growing of strawberries with control of insects and mulching/ fertilization. Acta. Hort., 567: $419-422$.

Trevisan, S.; Pizzeghello, D.; Ruperti, B.; Francioso, O.; Sassi, A.; Palme, K.; Quaggiotti, S. and Nardi, S. (2009): Humic substances induce lateral root formation and expression of the early auxin- responsive IAA 19 gene and DR5 synthetic element in Arabidopsis. Plant Biol. 12: $604-$ 614. 
Turemis, N. (2002): The effects of different organic deposits on yield and quality of strawberry cultivar Dorit (216). Acta. Hort., 567: 507 - 510.

Turkmen, O. Dursun, A. Turan, M. and Erdinc, C. (2004): Calcium and humic acid effect seed germination, growth and nutrient content of tomato (Lycopersicon esculentum L.) seedlings under saline soil conditions, Acta Agriculturae Scandinavica, Section B - Plant Soil Sci. 54 (3): 168 $-174$.

Vonshak, A. (1986): Laboratory techniques for the cultivation of microalgae. In Handbook of Microalgal Mass Culture, ed. A. Richmond, pp. 117 145 Boca Raton: CRC Press.

Vonshak, A. and Richmond, A. (1988): Mass production of blue- green algae Spirulina. An overview Biomass 15: 233 - 247.

Wilde, S. A.; Corey, R. B.; Layer, J. G. and Voigt, G. K. (1985): Soils and Plant Analysis for Tree Culture. Oxford and IBH publishing Co., New Delhi, India.

Zarrouk, C. (1966). Contribution al, etude d une cyanophycec. Influence de divers facteurs physigues et chimigues sur la croissance et la photosynthese de spirulina maxima (setch et Garmax) Geitler. Ph.Dr. These Univ. Paris, France.

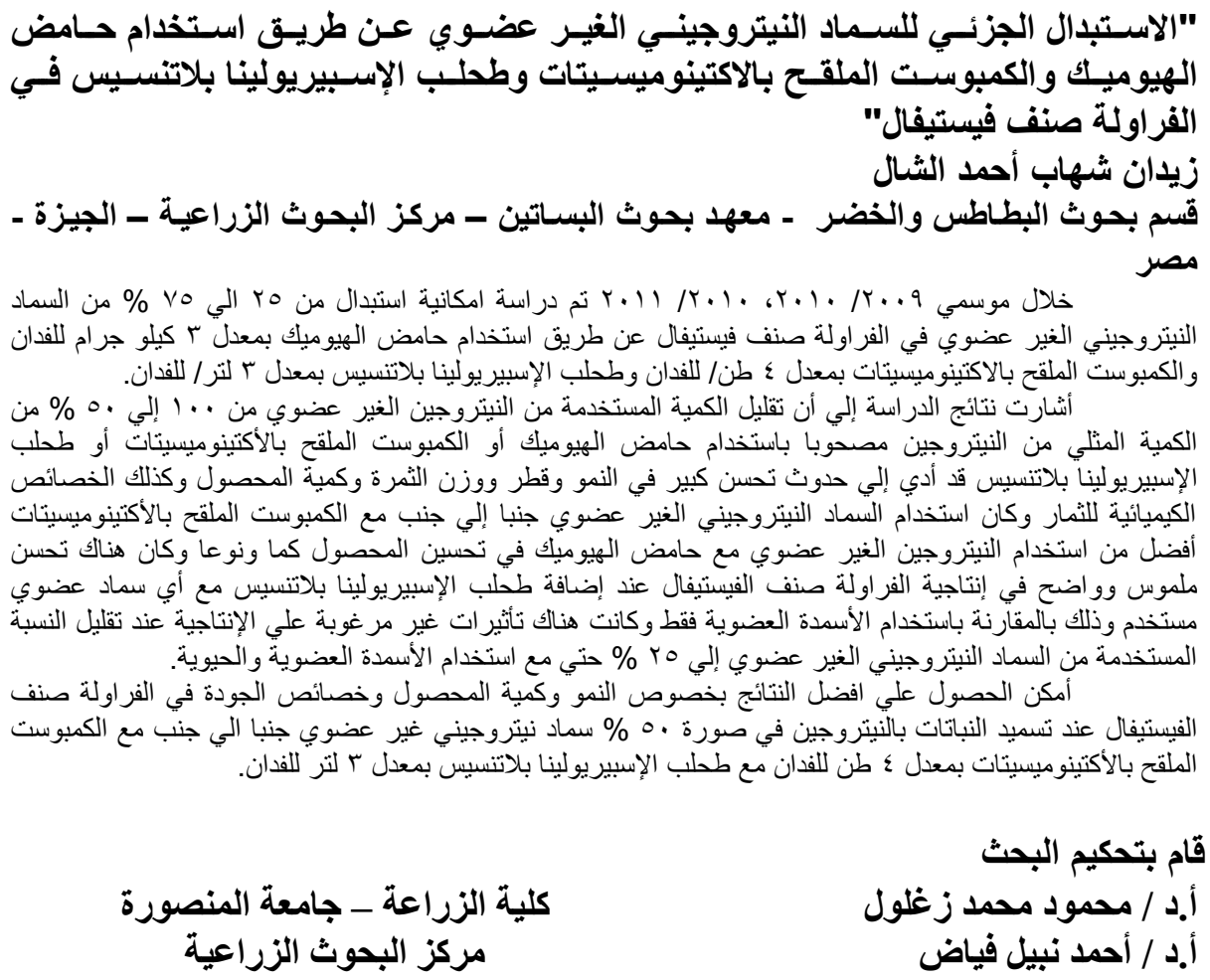

كلية الزراعة - جامعة المنصورة

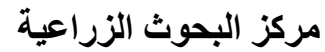


EI- Shall,Z. S. A. 
Table (4): Effect of partial replacement of inorganic $\mathbf{N}$ fertilizer with compost enriched with actinomyces, humic acid and Spirulina platensis algae on growth, fruit diameter and weight as well as yield of strawberry cv. Festival during 2010 and 2011 seasons.

\begin{tabular}{|c|c|c|c|c|c|c|c|c|c|c|c|c|}
\hline \multirow[t]{2}{*}{ Inorganic $\mathrm{N}$ as well as organic and biofertilization treatments } & \multicolumn{2}{|c|}{$\begin{array}{c}\text { Plant height } \\
\text { (cm.) }\end{array}$} & \multicolumn{2}{|c|}{$\begin{array}{c}\text { No. of } \\
\text { leaves/ plant }\end{array}$} & \multicolumn{2}{|c|}{$\begin{array}{c}\text { Fruit } \\
\text { diameter } \\
\text { (cm.) }\end{array}$} & \multicolumn{2}{|c|}{$\begin{array}{l}\text { Fruit weight } \\
\text { (g.) }\end{array}$} & \multicolumn{2}{|c|}{$\begin{array}{l}\text { Early yield } \\
\text { (ton/ fed.) }\end{array}$} & \multicolumn{2}{|c|}{$\begin{array}{c}\text { Total yield (ton/ } \\
\text { fed.) }\end{array}$} \\
\hline & 2010 & 2011 & 2010 & 2011 & 2010 & 2011 & 2010 & 2011 & 2010 & 2011 & 2010 & 2011 \\
\hline Inorganic $\mathrm{N}$ at $60 \mathrm{~kg} / \mathrm{fed}$. & 13.0 & 14.1 & 5.7 & 5.9 & 2.40 & 2.41 & 9.62 & 9.67 & 1.94 & 1.76 & 10.20 & 9.41 \\
\hline $\begin{array}{l}75 \% \text { inorganic } N+\text { compost enriched with actinomyces (4 } \\
\text { T/Fed.) }\end{array}$ & 15.0 & 16.0 & 7.0 & 6.6 & 2.51 & 2.52 & 9.74 & 9.79 & 2.11 & 2.11 & 11.69 & 10.48 \\
\hline $75 \%$ inorganic $\mathrm{N}+$ compost enriched with actinomyces + S & 15.6 & 165 & & & & 2.57 & 9.82 & 9.88 & & & & \\
\hline humic acid at $3 \mathbf{~ k g . / ~ f e d . ~}$ & 13.8 & 14.7 & 6.9 & 6.5 & 2.44 & 2.47 & 9.58 & 9.63 & 2.00 & 1.97 & 10.46 & 11 \\
\hline d. + S (3 L/ Fed.) & 14.4 & 15.3 & 7. & 6. & 2.47 & 2.51 & 9.64 & 9.71 & 2.2 & 2.01 & & \\
\hline $50 \%$ & 16.5 & 17. & & & 2.74 & 2.77 & 10.41 & 10.50 & 2.43 & 2.61 & & 11. \\
\hline $50 \%$ inc & 16.8 & 17.9 & 7.4 & 7.0 & 2.79 & 2.83 & 11.11 & 11.39 & 2.78 & 2.78 & 13.20 & 12. \\
\hline $50 \%$ inorganic $\mathrm{N}+$ humic acid at $3 \mathrm{~kg} . / \mathrm{fed}$. & 15.6 & 17.2 & 7.1 & 6.8 & 2.60 & 2.64 & 10.01 & \begin{tabular}{|l|}
10.10 \\
\end{tabular} & 2.62 & 2.51 & 11.11 & 11.11 \\
\hline $50 \%$ & 16.4 & 17.5 & 7.2 & 6.9 & 2.65 & 2.69 & 10.15 & 10.25 & 2.6 & 2.61 & & 11.42 \\
\hline $25 \%$ & 12.1 & 12.7 & 5.5 & 5 & 2.31 & 2.30 & 9.51 & 9.50 & 1.81 & 1.72 & 21 & 7.71 \\
\hline c N + Compost enriched with actinomyces + S & 12.4 & 13.4 & 5.6 & 5.5 & 2.35 & 2.33 & 9.56 & 9.55 & 1.80 & 1.81 & 8.61 & 8.41 \\
\hline c N + humic acid at $3 \mathrm{~kg} . / \mathrm{fed}$ & 11.1 & 11.4 & 5.0 & 5.0 & 2.21 & 2.20 & 9.41 & 9.42 & 1.51 & 1.58 & 7.49 & 7.26 \\
\hline $25 \% \mathrm{i}$ & 11.8 & 12.0 & 5.3 & 5. & 2.26 & 2.24 & 9.46 & 9.47 & 1.7 & 1.70 & & 7.90 \\
\hline New L.S.D at $5 \%$ & 0.6 & 0.6 & 0.6 & 0.6 & 0.04 & 0.03 & 0.05 & 0.04 & 0.07 & 0.09 & 0.74 & 0.82 \\
\hline
\end{tabular}

S = Spirulina platensis algae (3 L/ Fed.) 
Table (5): Effect of partial replacement of inorganic $\mathbf{N}$ fertilizer with compost enriched with actinomyces, humic acid and Spirulina platensis algae on some chemical characteristics of the fruits of strawberry cv. Festival during 2010 and 2011 seasons.

\begin{tabular}{|c|c|c|c|c|c|c|c|c|c|c|c|c|}
\hline \multirow[t]{2}{*}{ Inorganic $\mathrm{N}$ as well as organic and biofertilization treatments } & \multicolumn{2}{|c|}{ T.S.S \% } & \multicolumn{2}{|c|}{$\begin{array}{c}\text { Total acidity } \\
\%\end{array}$} & \multicolumn{2}{|c|}{$\begin{array}{c}\text { Total sugars } \\
\%\end{array}$} & \multicolumn{2}{|c|}{$\begin{array}{l}\text { Reducing } \\
\text { Sugars \% }\end{array}$} & \multicolumn{2}{|c|}{$\begin{array}{c}\text { Sucrose } \\
\%\end{array}$} & \multicolumn{2}{|c|}{$\begin{array}{c}\text { Anthocyanin } \\
\text { s (mg/ } 100 \\
\text { FW) }\end{array}$} \\
\hline & 2010 & 2011 & 2010 & 2011 & 2010 & 2011 & 2010 & 2011 & 2010 & 2011 & 2010 & 2011 \\
\hline Inorganic $\mathrm{N}$ at $60 \mathrm{~kg} /$ fed. & 7.40 & 7.47 & 0.71 & 0.75 & 5.39 & 5.47 & 4.30 & 4.37 & 1.09 & 1.10 & 30.5 & 30.6 \\
\hline $\begin{array}{l}75 \% \text { inorganic } N+\text { compost enriched with actinomyces (4 } \\
\text { T/Fed.) }\end{array}$ & 7.61 & 7.68 & 0.67 & 0.72 & 5.60 & 5.66 & 4.55 & 4.62 & 1.05 & 1.04 & 33.9 & 34.0 \\
\hline $75 \%$ inorganic $N+$ compost enriched with actinomyces + S & 7.71 & 7.80 & 0.65 & 0.70 & 5.70 & 5.79 & 4.61 & 4.66 & 1.09 & 1.13 & 35.0 & 35.1 \\
\hline $75 \%$ inorganic $\mathrm{N}+$ humic acid at $3 \mathrm{~kg} . /$ fed. & 7.47 & 7.54 & 0.70 & 0.75 & 5.47 & 5.54 & 4.40 & 4.45 & 1.07 & 1.09 & 31.6 & 31.8 \\
\hline $75 \%$ inorganic $\mathrm{N}+$ humic acid at $3 \mathrm{~kg} . /$ fed. + S (3 L/ Fed.) & 7.55 & 7.62 & 0.68 & 0.73 & 5.54 & 5.60 & 4.46 & 4.52 & 1.08 & 1.08 & 32.7 & 32.8 \\
\hline $50 \%$ inorganic N + compost enriched with actinomyces & 8.11 & 8.20 & 0.61 & 0.66 & 6.10 & 6.18 & 4.83 & 4.90 & 1.27 & 1.28 & 38.2 & 38.3 \\
\hline $50 \%$ inorganic $\mathrm{N}+$ compost enriched with actinomyces + S & 8.61 & 8.71 & 0.58 & 0.63 & 6.59 & 6.71 & 4.90 & 4.96 & 1.69 & 1.75 & 38.9 & 39.0 \\
\hline $50 \%$ inorganic $\mathrm{N}+$ humic acid at $3 \mathrm{~kg} . / \mathrm{fed}$. & 7.81 & 7.88 & 0.65 & 0.71 & 5.80 & 5.87 & 4.71 & 4.78 & 1.17 & 1.09 & 35.9 & 36.0 \\
\hline $50 \%$ inorganic $\mathbf{N}+$ humic acid at $3 \mathrm{~kg} . / \mathrm{fed} .+\mathrm{S}$ & 7.95 & 8.04 & 0.64 & 0.69 & 5.94 & 6.00 & 4.77 & 4.85 & 1.17 & 1.15 & 37.1 & 37.2 \\
\hline $25 \%$ inorganic N + Compost enriched with actinomyces & 7.25 & 7.33 & 0.75 & 0.80 & 5.23 & 5.33 & 4.10 & 4.17 & 1.13 & 1.16 & 28.2 & 28.3 \\
\hline $25 \%$ inorganic N + Compost enriched with actinomyces + S & 7.30 & 7.37 & 0.74 & 0.78 & 5.30 & 5.36 & 4.20 & 4.25 & 1.10 & 1.11 & 29.4 & 29.5 \\
\hline $25 \%$ inorganic $\mathrm{N}+$ humic acid at $3 \mathrm{~kg} . /$ fed. & 7.10 & 7.15 & 0.80 & 0.85 & 5.10 & 5.14 & 4.00 & 4.07 & 1.10 & 1.07 & 26.0 & 26.3 \\
\hline $25 \%$ inorganic $\mathrm{N}+$ humic acid at $3 \mathrm{~kg} . /$ fed. + S & 7.17 & 7.25 & 0.77 & 0.82 & 5.16 & 5.24 & 4.05 & 4.10 & 1.11 & 1.14 & 27.1 & 27.8 \\
\hline New L.S.D at $5 \%$ & 0.04 & 0.04 & 0.09 & 0.10 & 0.04 & 0.03 & 0.03 & 0.03 & 0.08 & 0.09 & 1.0 & 1.0 \\
\hline
\end{tabular}

S = Spirulina platensis algae (3 L/ Fed.) 
Table (6): Effect of partial replacement of inorganic $\mathbf{N}$ fertilizer with compost enriched with actinomyces, humic acid and Spirulina platensis algae on some chemical components of the fruits of strawberry cv. during 2010 and 2011 seasons.

\begin{tabular}{|c|c|c|c|c|c|c|c|c|c|c|c|c|}
\hline \multirow[t]{2}{*}{ Inorganic $\mathrm{N}$ as well as organic and biofertilization treatments } & \multicolumn{2}{|c|}{$\begin{array}{l}\text { Vitamins C } \\
(\mathrm{mg} / 100 \mathrm{~g})\end{array}$} & \multicolumn{2}{|c|}{$\begin{array}{c}\text { Total } \\
\text { polyphenols } \\
(\mathrm{mg} / 100 \mathrm{~g})\end{array}$} & \multicolumn{2}{|c|}{$\begin{array}{l}\text { Fruit P } \\
(\mathbf{g} / \mathbf{k g ~ d m})\end{array}$} & \multicolumn{2}{|c|}{$\begin{array}{c}\text { Fruit K } \\
(\mathbf{g} / \mathbf{k g ~ d m})\end{array}$} & \multicolumn{2}{|c|}{$\begin{array}{l}\text { Fruit Ca } \\
(\mathbf{g} / \mathbf{k g ~ d m})\end{array}$} & \multicolumn{2}{|c|}{$\begin{array}{c}\text { Fruit Mg } \\
(\mathrm{g} / \mathrm{kg} \mathrm{dm})\end{array}$} \\
\hline & 2010 & 2011 & 2010 & 2011 & 2010 & 2011 & 2010 & 2011 & 2010 & 2011 & 2010 & 2011 \\
\hline Inorganic $\mathbf{N}$ at $60 \mathrm{~kg} /$ fed. & 48.5 & 48.0 & 0.50 & 0.49 & 2.91 & 2.95 & 16.60 & 16.67 & 3.60 & 3.66 & 1.31 & 1.33 \\
\hline $\begin{array}{l}75 \% \text { inorganic } N+\text { compost enriched with actinomyces (4 } \\
\text { T/Fed.) }\end{array}$ & 51.2 & 50.7 & 0.43 & 0.42 & 3.33 & 3.37 & 17.30 & 17.37 & 4.05 & 4.11 & 1.46 & 1.48 \\
\hline $75 \%$ inorganic N + compost enriched with actinomyces + S & 52.2 & 51.7 & 0.41 & 0.40 & 3.43 & 3.47 & 17.50 & 17.58 & 4.18 & 4.24 & 1.53 & 1.55 \\
\hline $75 \%$ inorganic N + humic acid at $3 \mathrm{~kg} . /$ fed. & 49.5 & 49.0 & 0.48 & 0.47 & 3.11 & 3.15 & 16.85 & 16.92 & 3.75 & 3.81 & 1.35 & 1.37 \\
\hline $75 \%$ inorganic $\mathrm{N}+$ humic acid at $3 \mathrm{~kg} . /$ fed. + S (3 L/ Fed.) & 50.3 & 49.8 & 0.46 & 0.46 & 3.22 & 3.25 & 17.00 & 17.09 & 3.90 & 3.96 & 1.40 & 1.42 \\
\hline $50 \%$ inorganic N + compost enriched with actinomyces & 54.7 & 54.2 & 0.31 & 0.30 & 3.85 & 3.90 & 18.22 & 18.30 & 4.71 & 4.78 & 1.72 & 1.75 \\
\hline $50 \%$ inorganic $\mathrm{N}+$ compost enriched with actinomyces + S & 55.9 & 55.2 & 0.30 & 0.30 & 3.95 & 3.97 & 18.45 & 18.52 & 4.82 & 4.90 & 1.76 & 1.79 \\
\hline $50 \%$ inorganic $\mathrm{N}+$ humic acid at $3 \mathrm{~kg} . / \mathrm{fed}$. & 53.3 & 52.7 & 0.38 & 0.37 & 3.55 & 3.59 & 17.71 & 17.81 & 4.30 & 4.36 & 1.60 & 1.63 \\
\hline $50 \%$ inorganic $\mathrm{N}+$ humic acid at $3 \mathrm{~kg} . /$ fed. + S & 54.0 & 53.5 & 0.35 & 0.35 & 3.75 & 3.78 & 18.00 & 18.09 & 4.50 & 4.56 & 1.66 & 1.69 \\
\hline $25 \%$ inorganic N + Compost enriched with actinomyces & 46.7 & 46.1 & 0.56 & 0.56 & 2.66 & 2.69 & 15.71 & 15.80 & 3.30 & 3.39 & 1.21 & 1.23 \\
\hline $25 \%$ inorganic N + Compost enriched with actinomyces + S & 47.5 & 47.0 & 0.54 & 0.53 & 2.76 & 2.81 & 16.11 & 16.20 & 3.43 & 3.50 & 1.25 & 1.28 \\
\hline $25 \%$ inorganic $\mathrm{N}+$ humic acid at $3 \mathrm{~kg} . / \mathrm{fed}$. & 45.0 & 44.5 & 0.61 & 0.61 & 2.48 & 2.51 & 15.19 & 15.25 & 2.96 & 3.11 & 1.11 & 1.14 \\
\hline $25 \%$ inorganic $\mathrm{N}+$ humic acid at $3 \mathrm{~kg} . /$ fed. + S & 45.7 & 45.2 & 0.59 & 0.58 & 2.57 & 2.60 & 15.41 & 15.50 & 3.15 & 3.24 & 1.15 & 1.17 \\
\hline New L.S.D at $5 \%$ & 0.6 & 0.7 & 0.02 & 0.03 & 0.09 & 0.10 & 0.21 & 0.21 & 0.10 & 0.11 & 0.03 & 0.03 \\
\hline
\end{tabular}

S = Spirulina platensis algae (3 L/ Fed.) 